\title{
Membangun karakter mahasiswa Indonesia melalui pendidikan moral
}

Oleh:

\author{
Hany Nurpratiwi
}

Institut Agama Islam Negeri Tulungagung

hany.nurpratiwi13@yahoo.com

revised: 04-03-2021

accepted: o8-o3-2021

\begin{abstract}
Abstrak
Karakter dan moral mahasiswa perlu ditumbuhkan dengan maksimal, sehingga mahasiswa tidak hanya unggul dibidang akademik, tapi juga unggul dibidang non akademik untuk menunjang identitas diri ditengah globalisasi. Oleh karenanya bagaimana menumbuhkan karakter yang mulia bagi mahasiswa Indonesia merupakan hal terpenting yang harus segera dilakukan. Melalui penelitian ini diharapkan diperoleh gagasan atau strategi menumbuhkan karakter mulia di kalangan mahasiswa Indonesia. Penelitian dilakukan dengan menggunakan kajian pustaka yaitu mengumpulkan dan menganalisis sumber dan fakta dari literature seperti buku, jurnal, makalah dan tesis. Pengumpulan data dilaksanakan dengan Teknik membaca baik membaca semantik maupun simbolik. Hasil penelitian menemukan bahwa pendidikan karakter di lingkungan pendidikan tinggi tetap harus dilaksanakan untuk memperkuat dan menyemaikan karakter mulia di kalangan mahasiswa. Dosen memiliki peran dalam pengembangan karakter dan moral mahasiswa. Melalui keteladanan yang diajarkan dosen di lingkungan akademik, mahasiswa akan melakukan proses imitasi dan cenderung menjadikan dosen sebagai role model dalam bertindak.

Kata kunci: dosen, mahasiswa, pendidikan karakter.
\end{abstract}

\begin{abstract}
The character and morals of students need to be developed to the maximum, so that students are not only superior in academics, but also in non-academic fields to support their identity in the midst of globalization. Therefore, how to cultivate noble character for Indonesian students is the most important thing that must be done immediately. Through this research, it is hoped that ideas or strategies will be obtained to foster noble character among Indonesian students. The research was conducted using literature review, namely collecting and analyzing sources and facts from literature such as books, journals, papers and theses. Data collection was carried out with reading techniques both semantic and symbolic reading. The results of the study found that character education in the higher education environment must still be carried out to strengthen and nurture noble character among students. Lecturers have a role in developing student character and morale. Through exemplary teachings by lecturers in an academic environment, students will carry out an imitation process and tend to make lecturers as role models in acting.
\end{abstract}

Keyword: lecture, student, character education 


\section{Pendahuluan}

Lunturnya kepribadian nasional, degradasi moral, serta hilangnya nilai-nilai moralitas luhur di kalangan generasi muda, menjadi permasalahan yang urgen. Derasnya arus informasi global yang berdampak pada penetrasi budaya asing memiliki pengaruh yang signifikan terhadap pola pikir, sikap dan perilaku generasi muda. Di kalangan generasi muda kita persoalan tersebut dapat dilihat pada kurang berkembangnya sikap kemandirian, kreativitas serta produktivitas, sehingga generasi kita kurang dapat berpartisipasi secara maksimal dalam proses membangun karakter bangsa. Dampak negatif yang dapat dirasakan secara langsung adalah penyalahgunaan narkoba dan zat adiktif lainnya (NAPZA), tawuran pelajar, mahasiswa, kriminalitas, minuman keras, penyebaran penyakit HIV/AIDS dan lainnya. Permasalahan-permasalahan tersebut apabila tidak memperoleh perhatian dan penanganan secara bijaksana dan sistematis, akan memiliki dampak yang lebih luas dan dapat mengganggu kesinambungan, kestabilan dalam pembangunan nasional. Muara dari segala kekhawatiran tersebut adalah ancaman terhadap integrasi bangsa yang semakin terbuka lebar (Fathurrohmah, 2019).

Dalam beberapa dasawarsa terakhir terjadi kecenderungan baru di mana kesadaran akan nilai mulai tumbuh kembali. Kecenderungan tersebut terjadi secara global dan dapat digambarkan sebagai suatu titik balik dalam perkembangan peradaban manusia. Orang mulai berbicara tentang nilai, bahkan untuk bidang yang dianggap bebas nilai sekalipun seperti sains dan teknologi. Titik balik berikutnya yang menempatkan isu-isu tentang nilai sebagai fokus perhatian adalah semakin populernya kecerdasan emosional dan kecerdasan spiritual. Di Indonesia mulai berkembang pendidikan dan pengajaran yang mengintegrasikan ilmu pengetahuan dan teknologi dengan aspek keimanan dan ketaqwaan terhadap Tuhan Yang Maha Esa (Sudrajat, 2011: 19). Bersamaan dengan itu sekolah-sekolah berusaha menciptakan iklim yang kondusif bagi tumbuhnya kesadaran nilai, moral, dan keagamaan bagi peserta didiknya. Pendidikan karakter menjadi program primadona yang ditawarkan oleh berbagai lembaga pendidikan baik di tingkat dasar maupun menengah. Namun, sayangnya penguatan pendidikan karakter sebagaimana diamanatkan oleh undang-undang belum mampu menjawab persoalan serius yang dihadapi bangsa Indonesia yaitu tumbuhnya karakter mulia sebagai manusia Indonesia utama. 
Hampir seluruh jenjang pendidikan telah mengimplementasikan pendidikan karakter, namun belum ada tanda-tanda peningkatan kualitas karakter manusia Indonesia ke arah yang lebih baik. Korupsi masih terjadi, kejahatan juga tetap merajalela, kekerasan dan penyalahgunaan narkotika masih tetap selalu terdengar dalam berita-berita di media massa. Diperlukan solusi yang futuristik dan kreatif bagaimana karakter positif sebagai manusia yang utama dapat berkembang dengan baik. Sudrajat dan Wijayanti (2018: 48) menyatakan bahwa the development community was dynamic, and social problems that today's constantly evolving needs attention and sensitivity of all elements the nation not only from the experts and observers, but also the educational community that has a strategic role as a medium the agent of change.

Pendidikan sebagai wahana untuk memanusiakan manusia terikat oleh dua misi penting yaitu homonisasi dan humanisasi. Sebagai proses homonisasi, pendidikan mempunyai kepentingan untuk memposisikan manusia sebagai makhluk yang memiliki keserasian dengan habitat ekologinya. Manusia diarahkan untuk mampu memenuhi kebutuhan-kebutuhan biologisnya seperti makan, minum, sandang, dan perumahan. Dalam proses tersebut pendidikan dituntut untuk mampu mengarahkan manusia pada cara-cara pemilihan dan pemilahan nilai sesuai dengan kodrat biologis manusia.

Thomas Lickona (1991) menilai pendidikan nilai merupakan hal yang sangat esensial dalam kesuksesan masyarakat yang demokratis. Lebih jauh Lickona (1991: 6) mengemukakan bahwa moral education is not a new idea. It is, in fact, as old as education itself. Down through history, in countries all over the world, education has had two great goals: to help young people become smart and to help them become good. Jadi pendidikan moral sudah ada sejak pendidikan itu sendiri ada. Sepanjang sejarahnya pendidikan mempunyai dua tujuan yaitu: membantu anak-anak muda menjadi cerdas dan baik. Berbagai pendekatan untuk mengimplementasikan pendidikan moral umumnya berangkat dari pemahaman dan kultur masing-masing. Bagi bangsa Indonesia pendekatan komprehensif merupakan alternatif yang tepat karena dapat memberikan efek dari berbagai arah.

Metode yang dapat dilakukan dalam kerangka pendekatan komprehensif antara lain: inkulkasi (inculcation) yaitu penanaman nilai, keteladanan (modeling), facilitation yaitu memfasilitasi peserta didik peserta didik untuk mengatasi permasalahan-permasalahan yang melingkupinya, dan terakhir skill building yaitu pengembangan ketrampilan berfikir kritis (Zuchdi, 2013). Dengan metode-metode 
tersebut maka diharapkan peserta didik dapat mengenal, memahani, melaksanakan nilai-nilai tersebut dan sanggup menghadapi dilemma-dilema nilai. Dengan pendekatan yang demikian upaya pembentukan manusia Indonesia yang berkarakter kuat melalui dunia pendidikan dapat diwujudkan secara nyata.

Dosen memiliki peran penting dalam menumbuhkan karakter mahasiswa. Proses pengembangan karakter terjadi sepanjang kehidupan manusia. Dosen yang berkarakter akan menjadi teladan bagi mahasiswa sehingga mereka memiliki moral yang baik. Hal terpenting yang harus dimiliki dosen sebelum mendidik mahasiswa adalah personal karakter yang sesuai dengan tugas utamanya sebagai dosen. Belakang ini banyak kita jumpai sarjana lulusan dari perguruan tinggi belum tentu memiliki karakter dan moral yang unggul. Fenomena tersebut harus dicermati dan segera ditangani oleh berbagai pihak (perguruan tinggi, masyarakat dan pemerintah) sehingga output dari perguruan tinggi tidak hanya unggul dalam bidak akademik tetapi juga bermoral dan berkarakter yang unggul. Dengan kecerdasan intelektual diharapkan siswa mampu mengembangkan berpikir logis-matematis, selain itu siswa diharapkan mempunyai kecakapan emosional yang mencakup pengendalian diri, semangat dan kemampuan untuk memotivasi diri sendiri.

Karakter dan moral yang baik dapat tumbuh dengan baik di dalam lingkungan yang demokratis. Astuti dan Sudrajat, (2020) menyatakan bahwa social justice focuses on the human condition, similarities, and differences, avoiding discrimination and forms of oppression. Social justice in the context of inclusive education refers to the educational process in which the system, policy, curriculum, and learning center are centered on children who have different backgrounds to always understand each other and respect one another. Di samping tetap menekankan aspek akademik, yang juga sangat esensial adalah penanaman pendidikan nilai-nilai moral dan keadilan sosial dalam masyarakat menuju kehidupan masyarakat sipil yang demokratis.

Nilai-nilai perdamaian sebagai alternatif pola pembelajaran yang menyeluruh dapat membantu menyiapkan para generasi muda agar mempunyai kemandirian, kecerdasan intelektual, religius, kultural dan sosial yang siap memecahkan segala permasalahan sosial. Implementasi dari pendidikan nilai-nilai perdamaian sebaiknya diberikan pada subjek didik lebih dini, hal ini dimaksudkan agar anak mulai dari dasar sudah mulai tertanam nilai-nilai tingkah laku yang baik sehingga mampu berpikir kritis, kreatif dalam menghadapi permasalahan dalam masyarakat.

Kecerdasan kultural juga tidak mungkin dipisahkan dengan kecerdasan 
intelektual, karena kecerdasan cultural terkait dengan gagasan, konsep dan pemikiran yang meliputi ranah kognisi, perilaku dan produk. Gagasan dan pemikiran dapat di aktualisasikan dalam bentuk ketrampilan dan kecerdasan sosial yang mencakup kecakapan berkomunikasi dan berkolaborasi (kerjasama). Maka dari itu dengan muatan cerdas intelektual, kultural dan sosial, kecerdasan rohani mempunyai kedudukan sangat penting karena berada pada potensi imajinatif kreatif yang memberikan arah yang jelas kemana dan bagaimana imajinatif berpikir kreatif harus diarahkan (Zuchdi, 2013). Pengembangan berbagai kecerdasan secara integrative dapat di implementasikan melalui pendekatan pendidikan nilai-nilai perdamaian. Caranya dengan mengintegrasikan nilai-nilai yang ditargetkan akan dikembangkan ke dalam proses pembelajaran di setiap mata pelajaran.

\section{Metode Penelitian}

Metode penelitian yang digunakan dalam penulisan artikel ini adalah metode kepustakaan. Disini penulis menggunakan literature berupa kepustakaan, seperti buku, catatan, skripsi, jurnal dan beberapa hasil penelitian yang relevan. Selain menggunakan studi kepustakaan, penulis juga melakukan pengamatan pribadi terkait iklim dan karakter masyarakat dilingkungan kampus. Proses pengumpulan data yang dilakukan melalui pengumpulan bahan pustaka atau literature berupa buku, artikel, hasil penelitian, maupun newsletter. Di samping melalui perpustakaan, penelitian juga dilaksanakan melalui penelusuran pustaka melalui internet, khususnya untuk mencari hasil penelitian dari jurnal. Esensi dari kegiatan penelitian yang dilakukan adalah membaca referensi lain yang mendukung, baik secara simbolik maupun semantik.

Membaca simbolik merupakan kegiatan membaca yang tidak menyeluruh, yaitu menangkap sinopsis dari bagian-bagian kecil buku. Tahap membaca simbolik penting artinya untuk menentukan peta penelitian serta mengembangkannya menjadi lebih luas. Sedangkan membaca semantik artinya: peneliti mengumpulkan data dengan membaca teks atau naskah secara lebih terinci, terurai dan berusaha untuk menangkap esensi dari data tersebut (Kaelan, 2005: 157). Melalui kegiatan membaca berbagai bahan penelitian, kemudian dirumuskan opsi penyelesaian masalah untuk memberikan perspektif atas problem statement yang ditentukan yaitu pembangunan karakter mahasiswa Indonesia. 


\section{Hasil Penelitian dan Pembahasan}

Karakter diartikan sebagai tabiat; watak; sifat-sifat kejiwaan, akhlak atau budi pekerti yang membedakan seseorang dengan yang lain. Karakter seseorang tidak hanya dilihat dari perilaku yang baik tetapi dilihat dari keseluruhan pola dan tingkah laku sebagai individu. Karakter menggambarkan kualitas moral seseorang yang tercermin dari segala tingkah lakunya yang mengandung unsur keberanian, ketabahan, kejujuran dan kesetiaan. Seseorang yang kompeten dan memiliki karakter merupakan sumber daya manusia yang handal, berwatak, cerdas dan kompetitif dalam menghadapi tantangan global. Karakter yang melekat dalam diri mahasiswa merupakan akumulasi dari kebiasaan, sikap, pola piker, dan kultur mereka yang telah terbentuk dan tertanam selama puluhan tahun di bawah lingkungan pendidikannya. Dalam konteks mahasiswa dimana mereka telah menjadi individu yang dewasa, maka karakter layaknya merupakan identitas diri. Berkowitz (2002: 53) berpendapat bahwa identity is the individual's self-constructed sense of self. Recent interest has turned to the concept of moral identity, the centrality of being good to one's self-concept, because of its appearance in studies of living and hypothetical moral exemplars. Adolescence is a critical time for the formation of a sense of self, an identity. Therefore, it is likely that the formation of a sense of oneself as a moral agent develops at the same time.

Sudrajat (2011) menyatakan bahwa pendidikan juga tidak dapat dilepaskan dengan otonomisasi atau pembebasan serta pembentukan pola berpikir kritis sebagai penyiapan generasi muda untuk menjadi warga masyarakat. Pemerintah Indonesia turut memberi dukungan terkait pembentukan dasn penerapan pendidikan karakter, dalam Peraturan Pemerintah No.17 th 2010, pasal 85 ayat 2 dijelaskan bahwa Perguruan Tinggi memiliki tujuan untuk membentuk insan yang beriman dan bertaqwa kepada Tuhan YME, berakhlak mulia, bekepribadian luhur, sehat, berilmu dan cakap, kritis dan kreatif, inovatif, mandiri, percaya diri, berwirausaha, demokratis dan bertanggung jawab. Koesoema (2007: 118) menggarisbawahi pentingnya jalinan relasional antar individu di dalam dunia pendidikan itu sendiri dengan lembaga lain seperti keluarga dan masyarakat. Jalinan ini sangat mempengaruhi proses pendidikan bagi anak sebab setelah sekolah, keluarga, dan lingkungan masyarakat merupakan tempat di mana anak tinggal dan melakukan aktivitas sosial. Oleh karenanya hubungan yang sinergis di antara sekolah, keluarga, dan masyarakat harus dibangun secara konstruktif. Hal ini sangat urgen mengingat 
otonomisasi dan pembentukan pola berfikir kritis merupakan salah satu pilar civil society yang didambakan bersama.

Karakter mahasiswa bisa dikembangkan dan tumbuh secara perlahan melalui proses pendidikan. Perguruan Tinggi sebagai wadah formal untuk mahasiswa melaksanakan proses pendidikan dan berperan untuk melanjutkan proses penanaman karakter. Pendidikan karakter memiliki banyak fungsi, di sini dijabarkan fungsi pendidikan karakter menurut Kemendiknas (2011) adalah (1) membangun kehidupan kebangsaan yang multikultural; (2) membangun peradaban bangsa yang cerdas, berbudaya luhur, dan mampu berkontribusi terhadap pengembangan kehidupan umat manusia; mengembangkan potensi dasar agar berhati baik, berpikiran baik, dan berperilaku baik serta keteladanan baik; (3)membangun sikap warganegara yang cinta damai, kreatif, mandiri, dan mampu hidupberdampingan dengan bangsa lain dalam suatu harmoni.

UU Sistem Pendidikan Nasional No. 22 tahun 2003, pasal 1, ayat 1 menyatakan bahwa Pendidikan adalah usaha sadar dan terencana untuk mewujudkan suasana belajar dan proses pembelajaran agar peserta didik secara aktifmengembangkan potensi dirinya untuk memiliki kekuatan spiritual keagamaan, pengendalian diri, kepribadian , kecerdasan, akhlak mulia, serta ketrampilan yang diperlukan dirinya, masyarakat, bangsa dan negara. Sumber daya manusia sangat diperlukan dalam proses terjadinya pendidikan guna menstransfer, memfasilitasi dan membimbing peserta didik. Pendidikan tinggi merupakan tumpuan akhir seluruh jenjang pendidikan dan sebagai wahana pembentukan sarjana yang memiliki budi pekerti luhur, melangsungkan nilai-nilai kebudayaan, memajukan kehidupan dan membentuk satria pinandita (Harsono, 2008).

Peran dosen adalah mendidik, mengajar, melatih, membimbing dan mengevaluasi kegiatan pendidikan. Peran dosen pembimbing akademik dalam pembentukan karakter mahasiswa adalah upaya membangun dan mengubah paradigma berfikir mahasiswa supaya menjadi manusia yang lebih dewasa (Partawibawa, Fatahudin, \& Widodo, 2014). Melihat fenomena amoral yang banyak terjadi dikalangan remaja juga menimbulkan keprihatinan di dunia pendidikan. Meskipun bukan satu-satunya faktor pendorong dalam membentuk karakter mahasiswa, namun dosen memiliki peran yang signifikan dalam membentuk karakter mahasiswa dan mengawasi pola perilaku mahasiswa dalam kehidupan sehari-hari dilingkungan kampus. Peran dosen dalam menumbuhkan karakter mahasiswa perlu 
mendapatkan dukungan dari lingkungan kampus, masyarakat dan pemerintah. Keberhasilan implementasi pendidikan karakter di perguruan tinggi dipengaruhi oleh beberapa aspek yaitu:

a. Budaya kampus dan praktik-praktik interpersonal yang menjamin bahwa mahasiswa diperlakukan dengan perhatian dan hormat,

b. Dosen dan staff yang berada dilingkungan kampus menjadi model karakter yang baik bagi mahasiswa, menghidupkan nilai-nilai dalam interaksi keseharian dengan mahasiswa,

c. Memberikan kesempatan pada mahasiswa untuk memiliki otonomi dan pengaruh pengelolaan perguruan tinggi, seperti memberikan wadah untuk menampung aspirasi mahasiswa,

d. Memberikan kesempatan kepada mahasiswa untuk refleksi, berdebat atau berkolaborasi mencari pemecahan isu moral,

e. Sharing visi dan sence of collectivity dan responsibility,

f. Social skiil training yang artinya kampus menyelenggarakan pelatihan bagi mahasiswa supaya bisa melakukan penyesuaian jangka panjang dengan memperkuat keterampilan pemecahan masalah interpersonal (Berkowits, 2002).

Karakter mengacu pada serangkaian sikap, perilaku, motivasi dan ketrampilan. Karakter mahasiswa bisa dikembangkan dan tumbuh secara perlahan melalui proses pendidikan (Berkowitz, 2002). Perguruan tinggi sebagai wadah formal untuk mahasiswa melaksanakan proses pendidikan dan berperan untuk melanjutkan proses penanaman karakter. Pada akhirnya karakter akan melekat pada diri seseorang dan kadang tanpa disadari. Menjadi pribadi yang berkarakter berarti menjadi pribadi yang handal, berkepribadian baik, bermoral unggul dan menjadi aset mahal bagi bangsa dan negara.

Dalam pandangan Ibrahim dan Robandi (2020) penguatan agensi moral sebagai sebuah komponen spiritual dari manusia yang istimewa perlu memperoleh penekanan. Agensi moral adalah otonomi atau kehendak manusia untuk menjadi penyebab, pemegang kontrol dan pencipta laku moral yang senantiasa melakukan kebajikan dan menjauhi keburukan secara sadar, bahkan menjadi agensi moral adalah tujuan hidup dan pola perilaku yang dilakukannya secara tulus dan penuh integritas. agensi moral adalah kemampuan manusia untuk menginterpretasi diri, dimulai dari pencarian makna dan nilai-nilai yang penting bagi kehidupan manusia, mengevaluasinya secara kualitatif, mengartikulasikannya dalam bentuk cita-cita moral yang luhur, serta mengaktualisasikannya dalam kehidupan secara konsisten 
dan menyeluruh. Berdasarkan pendapat para ahli dan peneliti mengenai Agensi Moral dapat diambil sintesis bahwa: dalam berbagai dimensi kehidupan, manusia dihadapkan pada lingkungan sosial yang berpotensi memberikan pengaruh baik atau buruk, pengaruh baik akan menguatkan karakter moral dalam diri manusia, sebaliknya pengaruh buruk berpotensi menimbulkan pelepasan moral dalam diri. Di sinilah proses regulasi diri yang menguatkan agensi moral dibutuhkan, memang tidaklah mudah, tapi perlu usaha yang kuat agar setiap manusia mampu menginterpretasi dirinya sebagai makhluk yang memiliki moralitas untuk mengarungi kehidupan secara etis dan normatif.

Perguruan tinggi adalah salah satu lembaga ilmiah yang menyelenggarakan program pendidikan akademik dalam sejumlah disiplin ilmu pengetahuan, program studi yang beragam. Proses pengajaran tidak hanya dilakukan melalui transfer of knowledge, tetapi juga mempersiapkan peserta didik untuk menjadi anggota masyarakat yang memiliki kemampuan akademik dan profesional dibidangnya, selain itu pengajaran juga dilakukan untuk membentuk manusia yang bermoral dan berbudi baik. Harapannya sebagai mahasiswa tidak hanya menguasai ilmu pengetahuan tetapi dengan moral baik, mahasiswa juga akan memiliki karakter yang baik.

Pendidikan Moral diartikan sebagai proses pendidikan yang ditujukan untuk mengembangkan nilai, sikap dan perilaku peserta didik yang memancarkan akhlak atau moral yang baik dan berbudi pekerti luhur. Melalui pendidikan moral peserta didik akan diberikan penerapan nilai dan perilaku yang positif (Daulay, 2004). Materi pendidikan moral mencakup ajaran dan pengalaman belajar untuk menjadi manusia bermoral dalam kaitannya dengan diri sendiri, sesama manusia, alam semesta dan Tuhan YME (Zuriah, 2010). Fokus utama dalam pendidikan moral adalah penanaman nilai-nilai positif dalam segala aspek kehidupan manusia.

Pendidikan moral mengandung beberapa komponen tentang moralitas, penalaran moral, perasaan kasihan dan mementingkan kepentingan orang lain dan tendensi moral (Zuchdi, 2013). Pendidikan moral dapat mengubah pola perilaku mahasiswa. Pendidikan moral juga dilatarbelakangi oleh lingkungan dan kebudayaan, serta iklim yang berkarakter akan menumbuhkan kesadaran moral yang baik. Kebiasaan saling menghormati, menyapa saat bertemu bahkan berjabat tangan dengan teman atau dosen perlu dijadikan sebagai kebiasaan. Selain itu fokus berdoa sebelum dan setelah perkuliahan, terciptanya iklim pembelajaran yang kondusif juga menjadi kebiasaan baik yang perlu dikembangkan. 
Metode adalah cara kerja yang bersistem untuk memulai pelaksanaan suatu kegiatan penilaian guna mencapai tujuan yang telah ditentukan. Pendidikan moral dapat disampaikan dengan metode langsung dan tidak langsung. Metode langsung dimulai dengan penentuan perilaku yang dinilai baik dengan memusatkan perhatian secara langsung pada ajaran tersebut melalui proses diskusi, ilustrasi dan pengucapan. Sedangkan metode tidak langsung dimulai dengan menciptakan situasi yang menginginkan perilaku baik yang dapat dipraktekan (Zuchdi, 2013). Pemilihan metode dalam proses pengajaran pendidikan moral dilakukan sesuai dengan kebutuhan dan keadaan lingkungan kampus. Terdapat berbagai macam metode, antara lain: metode demokratis, metode pencarian bersama, metode siswa aktif, metode keteladanan, metode live-in, metode penjernihan nilai (Paul Suparno, dkk, 2002). Metode demokratis dan pencarian bersama bisa menjadi pengawal dalam proses penerapan pendidikan moral di kampus. Metode demokratis memberikan ruang kepada mahasiswa untuk mencari tahu sendiri terkait tentang penerapan moral. Selain itu bisa juga diajarkan dengan pencarian bersama yang dilakukan melalui diskusi antara mahasiswa dan dosen. Tidak ada patokan yang kaku terkait metode yang harus digunakan dalam pelaksanaan pendidikan moral.

Metode komprehensif dilakukan melalui penanaman moral pemberian teladan dan penyiapan generasi muda agar dapat mandiri dengan mengajarkan dan memfasilitasi perbuatan keputusan moral secara bertanggung jawab dan ketrampilan terhadap hidup yang lain (Fathurrohmah, 2019). Selain itupendidikan moral dapat dilakukan dengan pendekatan yang bersifat integrated dengan melibatkan seluruh disiplin ilmu pengetahuan dan seluruh stekholder dilingkungan kampus, masyarakat dan pemerintah. Perkembangan moral dapat dilihat sebagai hasil suatu interaksi antara pelaksanaan, aturan, pengikut atau pembuatnya secara individual dengan kerangka jalinan aturan yang bersangkutan dengan menunjukkan esensi moral.

1. Level I

Kategori ini berisi anak usia 1 sampai 2 tahun. Peraturan yang dibuat masih bersifat sebagai motor activity. Belum ada kesadaran akan adanya peraturan. Semua gerakan belum dibimbing oleh pikiran tentang adanya peraturan yang harus ditaati,

\section{Level II}

Kategori ini berisi anak usia 2 sampai 6 tahun. Sudah mulai adakesadaran akan adanya peraturan, namun masih menganggap peraturan tersebut bersit suci, tidak 
boleh diganggu gugat oleh siapapun, merubah peraturan berarti membuat kesalahan besar. Dalam pelaksanaannya peraturan mereka masih bersifat eqosentrik, berpusat pada dirinya sendiri,

3. Level III

Kategori ini berisi anak usia 7 sampai 10 tahun. Pelaksanaan peraturan sudah mulai bersifat sebagai aktifitas sosial, sifat egosentrik sudah mulai ditinggalkan. Dalam tahap ini sudah ada keinginan kuat untuk memahami peraturan dan setia mengikuti peraturan tersebut. Sifat heteronom mulai bergeser pada sifat otonomi,

\section{Level IV}

Kategori ini berisi anak berusia 11 sampai 12 tahun. Kemampuan berfikir anak sudah mulai berkembang. Sudah ada kemampuan untuk berfikit abstrak, sudah ada kesadaran bahwa peraturan merupakan hasil kesepakatan bersama.

Mengacu pada teori perkembangan moral dari Jean Piaget (Muchson dan Samsuri, 2013) mahasiswa yang sudah dikategorikan sebagai dewasa sudah berada pada tataran diatas level IV. Mahasiswa sudah memiliki kemampuan kritis dan memiliki kesadaran akan peraturan yang dibuat lingkungan masyarakat. Mahasiswa dianggap mampu membedakan perbuatan yang baik dan buruk dan senantiasa mengembangkan perilaku positif. Mahasiswa yang memiliki karakter dan bermoral baik mampu menghadapi tantangan global dan memecahkan masalah secara personal. Keberhasilan pendidikan moral dikampus membantu mengurangi perilaku amoral yang bersifat negatif dalam pergaulan mahasiswa. Proses pelaksanaan penanaman pendidikan moral dilingkungan mahasiswa dapat kita lihat dari ciri-ciri berikut:

1. Cukup memperhatikan insting dan dorongan-dorongan spontan serta konstruktif,

2. Cukup membuka kondisi untuk membentuk pendapat yang baik,

3. Cukup memperlihatkan perlunya ada kepekaan untuk menerima dan sikap responsive,

4. Pendidikan moral memungkinkan memilih secara bijaksana mana yang benar dan mana yang salah.

Dosen adalah seseorang yang berdasarkan pendidikan dan keahliannya diangkat oleh penyelenggara perguruan tinggi dengan tugas utama mengajar pada perguruan tinggi yang bersangkutan. Perguruan tinggi akan survive dan memiliki keunggulan kompetitif dalam era globalisasi ini. Karakter dan moral akan memiliki peran penting didalamnya. Dosen yang berkarakter bisa menjadi modal besar dalam penanaman karakter dan pendidikan moral sehingga perguruan tinggi bisa survive menghadapi tangangan zaman. 
Proses pembelajaran yang dilakukan oleh dosen seharusnya tidak hanya untuk menyampaikan materi pembelajaran yang tertera dalam RPS. Dosen memiliki tugas untuk menjiwai seluruh proses proses pembelajaran, nilai moral, etika, karakter positif, nilai luhur seperti tanggung jawab daj kejujuran. Dengan kemampuan tersebut dosen dapat dikatakan sebagai dosen yang berkarakter. Dosen yang berkarakter akan menjadi role model mahasiswa dalam kehidupan sehari-hari dilingkungan perguruan tinggi maupun dalam lingkungan masyarakat.

Tri dharma adalah kewajiban pperguruan tinggi untuk menyelenggarakan pendidikan, penelitian dan pengabdian kepada masyarakat (UU No.12 Thn.2012, pasal 1 ayat 9). Pengamalan Tri Dharma Perguruan Tinggi oleh setiap dosen perlu dilakukan pantauan dan evaluasi. Impact positifnya akan diterima olehlingkungan kampus, karena seperti disebutkan diparagraf sebelumnya kalau dosen yang memiliki karakter dan bermoral baik akan membawa dampak positif bagi mahasiswa. Peran mahasiswa dalam aktualisasi tri dharma perguruan tinggi sangat di perlukan.

Mahasiswa diharapkan untuk menjadi mahasiswa yang lebih termotivasi dan sadar bahwa betapa pentingnya perananannya sebagai mahasiswa untuk mencapai tujuan nasional bangsa Indonesia yang tertuang dalam pembukaan UUD 1945 yaitu mencerdaskan kehidupan bangsa: 1) Dengan pendidikan, mahasiswa hendaknya punya dasar berpikir yang benar dalam memutuskan berbagai hal di dunia kampus maupun luar kampus. Dan seharusnya mahasiswa mempunyai hak untuk memperoleh pendidikan yang layak dan sesuai yang digelutinya, 2) penelitian dan pengembangan Merupakan bentuk implementasi dari ilmu pengetahuan yang diperoleh semasa proses pendidikan di perguruan tinggi. Dengan penelitian, para mahasiswa akan bertambah cakap dalam disiplin ilmunya, serta akan menjadi semakin paham, 3) pengabdian masyarakat bertujuan untuk membantu masyarakat agar mau dan mampu memenuhi kebutuhannya sendiri (Daulay, 2016).

Perguruan tinggi sebagai masyarakat ilmiah dituntut untuk berperan secara aktif positif dalam memecahkan permasalahan (problem solver) yang dihadapi masyarakat dengan menghasilkan ilmu yang siap pakai, dalam arti penemu masalah (problem finder). Dengan demikian ilmu yang diperoleh melalui penelitian dapat digunakan untuk menerangkan (to explain), meramalkan (to predict) atau peristiwa (event) di dalam kehidupan masyarakat, dunia usaha dan dunia industri. Oleh karena itu perguruan tinggi haruslah mampu menghasilkan lulusan (output) yang memiliki 
kepribadian tangguh, berkemampuan unggul, cerdas, kreatif sehingga mampu bersaing dengan bangsa-bangsa lain dalam menghadapi globalisasi

Peran perguruan tinggi hendaknya mampu menghasilkan lulusan yang memiliki kepribadian tangguh, berkemampuan unggul, cerdas, kreatif sehingga mampu bersaing dengan bangsa lain dalam menghadapi arus globalisasi (Yuliawati, 2012). Selain kepribadian tangguh, mahasiswa juga harus memiliki karakter dan moral yang baik sangat diperlukan supaya mahasiswa memiliki identitas diri. Kolaborasi antara ilmu pengetahuan dan karakter mahasiswa yang tangguh akan menciptakan mahasiswa yang bermoral dan profesional dibidangnya.

\section{Simpulan}

Perguruan tinggi sebagai salah satu lembaga pendidikan memiliki peran yang sangat penting terkait pembinaan moral dan karakter mahasiswa. Identifikasi moral dan karakter mahasiswa dapat dilihat dari aspek akademik dan non akademik. Sikap non akademik dilihat dari bagaimana pola perilaku mahasiswa sehari-hari dan wawasan kebangsaan. Sedangkan sikap akademik dapat dilihat dari sikap ilmiah dan kejujuran akademik. Peran dosen dan civitas akademik sangat dibutuhkan dalam upaya pembentukan karakter bangsa. Pendidikan karakter membentuk lingkungan yang positif untuk pertumbuhan moral.

Karakter mahasiswa bisa dikembangkan dan tumbuh secara perlahan melalui proses pendidikan. Perguruan Tinggi sebagai wadah formal untuk mahasiswa melaksanakan proses pendidikan dan berperan untuk melanjutkan proses penanaman karakter. Karakter mahasiswa bisa dikembangkan dan tumbuh secara perlahan melaluiproses pendidikan. Perguruan Tinggi sebagai wadah formal untuk mahasiswa melaksanakan proses pendidikan dan berperan untuk melanjutkan proses penanaman karakter.

Pelaksanaan Tri dharma perguruan tinggi dilakukan dosen melalui pengajaran, penelitian dan pengabdian kepada masyarakat. Melalui proses tersebut dosen melakukan proses internalisasi nilai-nilai luhur yang kemudian menjadi budaya kampus. Keteladanan harus muncul dari personality dosen dan diajarkan kepada mahasiswa. Dalam konteks ini dosen menjadi aktor penting dalam proses membangun karakter mahasiswa dan menumbuhkan kesadaran moral. 


\section{Referensi}

Astuti, D., S. \& Sudrajat. (2020). Promoting inclusive education for social justice in Indonesia, Proceedings of the 2nd International Conference on Social Science and Character Educations (ICOSSCE 2019), doi: 10.2991/assehr.k.200130.037

Bali, M. M, (2013). Peran dosen dalam membangun karakter mahasiswa. Humaniora, $4(2), 800-810$.

Berkowitz, M. W. (2002). The science of character education. Hoover Institution Press. tersedia pada https://www.hover.org.

Daulay, H. P., (2004). Pendidikan Islam dalam sistem pendidikan di Indonesia. Penerbit Kencana.

Devi, S. (2017). Peran dosen dalam mengembangkan karakter mahasiswa. Jurnal Pelangi. 2(2), 45-59.

Dian, A. M. (2012). Pendidikan karakter prespektif Islam. PT. Remaja Rosdakarya.

Fathurrohmah, (2019). Pendidikan karakter dalam kegiatan ekstrakurikuler, Jurnal Bidang Pendidikan Karakter, 3(1), 79-93.

Harsono, (2008). Pengelolaan perguruan tinggi. Pustaka Pelajar.

Ibrahim, T. \& Robandi, B. (2020). Representasi kesadaran agensi moral sebagai guru: studi fenomenologi pada mahasiswa pascasarjana Universitas Pendidikan Indonesia, Jurnal Pendidikan Karakter, 10(1). 6988. https://doi.org/10.21831/jpk.v10i1.30313

Kaelan. (2005). Metode penelitian kualitatif bidang filsafat. Pustaka Pelajar.

Koesoema D., A. (2007). Pendidikan karakter: strategi mendidik anak di zaman global. PT Gramedia Widiasarana Indonesia.

Lickona, T. (1991). Education for character: How our school can teach respect and responsibility. Bantam Books.

Partawibawa A., Fathudin S., \& Widodo A, (2014). Peran pembimbing akademik terhadap pembentukan karakter mahasiswa. Jurnal Pendidikan Teknologi dan Kejuruan, 22 (1), 2-8. https://doi.org/10.21831/jptk.v22i1.8851

Sudrajat \& Wijayanti, A. T. (2018). Temple as learning mediums in social studies: the 
perspective of multicultural education, Saudi Journal of Humanities and Social Sciences (SJHSS), 3 (8), 1014-1019. doi: 10.21276/sjhss.2018.3.8.17

Sudrajat. (2011). Membentuk pribadi mulia melalui pendidikan nilai: studi di SD Muhammadiyah Bodon Yogyakarta, Informasi 37(1), 19-39. doi: https://doi.org/10.21831/informasi.v1i1.4459

Suparno, P. (2002). Pendidikan budi pekerti di sekolah: Suatu tinjauan umum. Kanisius.

Zuchdi, D. (2013). Humanisasi pendidikan (kumpulan makalah dan artikel tentang pendidikan nilai). UNY Press.

Zuriah, S. (2008). Pendidikan moral dan budi pekerti dalam prespektif perubahan. Bumi Aksara.

Yuliawati, S. (2012), Kajian implementasi tri dharma perguruan tinggi sebagai fenomena pendidikan tinggi di Indonesia, Widya, 29(318), 28-33. 